\title{
Media education in primary schools in the Czech Republic
}

\author{
Iva Junová ${ }^{1 \mathrm{a}}$ \\ ${ }^{1}$ University of Hradec Králové, Faculty of Education, Department of Social Pedagogy, Rokitanského \\ 62, 50003, Hradec Králové, Czech Republic
}

\begin{abstract}
The article deals with realization of Media Education in Primary schools in the Czech Republic. The study introduction addresses the mass media influence on children's and the youth's socialization and gives reasons for the necessity of media education. There is a development of media education, mentioned in the text, followed by the description of an actual situation of media education in the Czech Republic. Another chapter depicts challenges that accompany the media education's execution at schools. The contribution presents the output of the media education survey in schools that was done by analysing documents and interviewing primary school teachers.
\end{abstract}

\section{Introduction}

The education and socialization in today's society are processes that are highly influenced by media. The medialization of children and youth take both directions. Media activity is aimed at children and young people as recipients and users (child as an object of medialization). On the other hand children themselves participate in media activity, create (child as a subject of medialization). Especially electronic media play a leading role in lives of contemporary children.

According to the data from the Czech Statistical Office, the IT equipment of schools is getting better. It is shown that IT equipment of primary, secondary and college was almost one hundred percent already in the year 2005, as well as the internet connection of schools. [8;9].

Rising influence of the internet on children is shown by the survey of Children and Youth national institute in 2010. Children at age of 10-15 were asked if they would rather get over the loss of television or the internet. While $32 \%$ would gladly give up the television, only $18 \%$ would give up the internet and only $11 \%$ would give up both [1].

The popularity of watching TV is confirmed by the survey in the area of media behaviour of watchers done by Mediaresearch Company since 2002. In the year 2011, there were 730 Czech children at age of 4-14 interviewed. The most common free time activity

\footnotetext{
${ }^{a}$ Corresponding author: iva.junova@uhk.cz
} 
(out of 28) is watching the TV. For $89 \%$ of children it is an everyday free time activity and another $8 \%$ watch TV at least once a week. Two fifths of Czech children are also connected to internet daily and one third at least once a week [5].

The stated survey has also shown that Czech children spend with media three and a half an hour daily in average. The time spent with media is another of monitored indicators in many surveys. For instance, Z. Helus [2] states that children (age 7-12) spend up to 2 hours daily with the television and up to 7 hours at weekends. Hofbauer [3] quotes the survey, according to which children spend with the television approximately 20 hours a week. In the last years, electronic media have been on the rise, because technology allows a non-stop access to the internet with help of the smartphones, tablets, laptops and other accessories.

\section{Media education at school}

\subsection{Origin and evolution of media education}

Along with the evolution of media technology throughout the history, contemplations on the influence of media emerged. The contemporary pedagogy tries to find answers to where, when and how it is best suited to realize the media education.

The first one to mention the educative potential of media in the print era is Jan Amos Komenský. As introduced by Mičienka, Jirák et al. [6], J.A. Komenský suggested the use of newspapers at school, because he perceived them as a source of enlightenment. He even demanded reading the newspaper to be a part of the lecture. In the work Labyrinth of the world and paradise of the heart, Komenský attempted to describe the mechanism of influence of media on society.

The use of media in education intensified in the era of electronic media. After the Second World War, there is an immense interest in the evolution of media education, first in the $50 \mathrm{~s}$ and the $60 \mathrm{~s}$ in USA as a reaction to commercialization of media, which was not as strong in Europe, and so the evolution here didn't begin before the $80 \mathrm{~s}$.

Since the 90s, in the light of technological advancement, we see the rise of interest in interactive media (computers, portable players, etc.) Excluding the media benefit, there are also risks described. The demand of media education has appeared to be increasing and media education has become a part of a national curriculum in many countries.

\subsection{Current media education}

First notices of media education in Czech environment can be found as early as in first half of 1990s. Pedagogic dictionary [7], explains media education as relatively young, evolving area of common education caused by the evolution of technology, transmitting the information. It supports a critical evaluation of functional use of media which is also a countermeasure against illiteracy.

In the 90s, first works dedicated to media influence problematic start to emerge. Integrated publications and textbooks of media education start to show up after the year 2000.

Media education was included into the Framework Educational Programme for Primary Education in 2000 and since 2007 it is taught as a cross-curricular subject in the Czech primary schools.

There are several ways to integrate media education into tuition: as a separate subject; as a part of other subjects; as a part of projects; as a combination of all. 
The aim of the subject "Media education is described in a Framework Educational Programme for Basic Education:

"The objective of Media Education is to equip pupils with a basic level of media literacy. This includes familiarizing oneself with certain basic findings regarding the functioning and societal role of contemporary media (history, structure) and acquiring skills which facilitate the individual's educated, active and independent interaction with the media message. This primarily involves the ability to analyse the message, to judge its trustworthiness and to determine its intent or associate it with other messages. It further involves orientation in media content and the ability to choose the proper medium for meeting various different needs - source of information, education, leisure time activities"[10].

\section{Research of media education realization in Czech schools}

\subsection{Objectives, starting-points and survey methods}

Media education is a relatively new part of the curriculum and so it is to be expected its implementation will be accompanied by difficulties and questions. Most of the surveys deal with the investigation of a level of media literacy of pupils and the ability to use technological applications. Jursová [4] researched media education from the point of view of the school. By series of interviews she ascertained the views of teachers and conditions of integrating the media education into tuition. It was shown that teachers consider the media education to be an important and useful way. They appreciated that aims, volume and demands on pupils' development were well concretized. On the other hand, the survey revealed some obstacles that might prevent the realization of media education.

This survey gave us a basis for our own research. Media education is a long-term topic of employees and students of Department of Social Pedagogy PdF UHK. Together with the students of master's degree of Social pedagogy, we organized a survey of Czech primary schools in years 2014-2015.

\subsection{Purpose of the study}

There were set two goals in our research.

- To describe and analyse the experience with implementation of media education into Czech schools

-To find out what the obstacles of the implementation are (tangible and social conditions)

\subsection{Research questions}

We were looking answers for these following questions:

a) In which form the media education is executed?

b) What is the content of media education program?

c) What are the obstacles of media education's implementation into tuition?

\subsection{Research methods}

We used a qualitative research strategy. The data collection was made by a semi-structured interview with teachers. For additional data we analysed documents, namely educational programs. 
For the data collection we selected 43 schools. In the sample we included both town schools and village schools, schools with both high and low population of pupils, basic schools and high schools.

From every school we chose one teacher, employed in media education (teaching subjects where media education is realized).

\section{Results}

Ad a)

Media education is most often executed in form of integrating of partial topics into other subjects. Topics of media education are usually integrated into subjects aimed at IT, Czech Language, Civics and Family Education. Only rarely is the media education offered as a standalone subject of study (6th -8 th grade). At some schools the media education is taught in a form of a project day, in an extent of several hours.

Ad b)

Media education usually incorporates traditional topics and techniques that aren't difficult to realize. For instance familiarization with different kinds of newspaper, magazines; print patterns; role of advertisement in life; newspaper production; websites; photo editing; production of presentation, animation; media message analysis; etc. Very sporadically other topics emerge that are harder to arrange and realize, but are also very important, for instance internet security; cyber bullying; identification of social values in media message; self-presentation with a feedback; violence in media; social networks and virtual relationships; etc.

Ad c)

Obstacles complicating the realization of media education at schools: insufficient funding and technical equipment for media education (particularly at smaller or country schools); absence of qualified pedagogue, who would be able to teach the media education properly; backlogs in concept and content of the subject (missing textbooks at smaller schools, lectures are executed intuitively, randomly, without thought-out concept and methodology); work load on pupils and time-demanding preparation for pedagogues.

\section{Discussion and Conclusion}

Media nowadays are an important part of children's everyday life within family, at school and in free time. Media possess a number of functions which support education and socialization while also introducing many risks. It proved necessary to teach children to handle media properly; such is the goal of media education. Our analysis shows that schools deem the media literacy very important part of preparation for life, but have reserves in its realization and execution.

Flaws can be found on two levels - material and personal (social). Some schools still have insufficient finances, which would cover the resources and technology for media education. On personal level there could be issues at the side of school management (negative attitude to media education's implementation), teachers (reluctance or inability to teach media education), pupils (reluctance to fulfil tasks, distorted perception of media usefulness) or their parents (lack of cooperation, absence of media education in family).

There are also reserves found in the subject's content. At smaller schools there is a lack of textbooks for media education; therefore teaching of media topics is done rather intuitively, at random, rather than according to a sophisticated concept and methodology.

From the forms of teaching media education schools prefer incorporating the topics into other subjects. Media education as a separate subject can be found exceptionally. 


\section{References}

1. Bocan, M., Hošková, I., Machalík, T., et al, Děti v ringu dnešního světa [Children in the ring of modern world]. Praha: NIDM MŠMT, (2012)

2. Helus, Z., Dítě v osobnostním pojetí [Child in a personality approach]. Praha: Portál., (2004)

3. Hofbauer, B, Kapitoly $\mathrm{z}$ pedagogiky volného času [Chapters from leisure time pedagogy]. České Budějovice: Jihočeská univerzita, (2010)

4. Jursová, J, Mediální výchova v praxi očima učitelů. In Z. Sikorová, M. Malčík \& K. Pavlica (Eds.), Český pedagogický výzkum v mezinárodním kontextu [Czech pedagogical research in the international context] (pp. 308 - 317). Ostrava: Pedagogická fakulta OU, (2010)

5. Kuncová, J, Děti a média: vyhrávají televize a internet [Children and media: television and internet dominate]. Available from: http://www.mediaguru.cz/2012/03/deti-amedia-vyhravaji-televize-a-internet/, (2012)

6. Mičienka, M., Jirák J. et al., Základy mediální výchovy [Fundamental media education]. Praha: Portál., (2007).

7. Průcha, J., Walterová, E., Mareš, J., Pedagogický slovník [Pedagogical Dictionary]. Praha: Portál., (1995).

8. Stašová, L., Junová, I., \& Adámková, T., Electronic Media in the Environment of the Contemporary Households and Families. Educational technologies (EDUTE 2012): proceedings of the 8th WSEAS international konference (pp. 111-116). Athens: World scientific and engineering academy and society, (2012).

9. Stašová, L., Slaninová, G., \& Junová, I., Nová generace [New generation]. Hradec Králové: Gaudeamus, (2015).

10. The Framework Educational Programme for Basic Education, Available from: http://www.msmt.cz/areas-of-work/basic-education-1, (2007) 